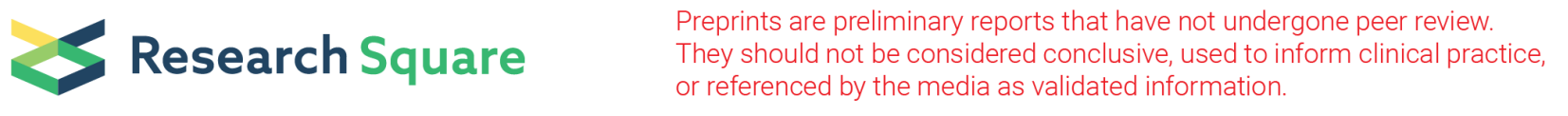

\title{
Perpetration of intimate partner violence among HIV positive couples: A Systematic Review
}

Felix Apiribu ( $\nabla$ fapiribu@yahoo.com)

Kwame Nkrumah University of Science and Technology College of Health Sciences https://orcid.org/0000-0003-4534-2568

Desmond Kuupiel

University of KwaZulu-Natal College of Health Sciences

Busisiwe Purity Ncama

University of KwaZulu-Natal College of Health Sciences

\section{Research}

Keywords: perpetrator, intimate partner violence, HIV, disclosure, factors

Posted Date: January 14th, 2020

DOI: https://doi.org/10.21203/rs.2.20721/v1

License: (c) (i) This work is licensed under a Creative Commons Attribution 4.0 International License. Read Full License 


\section{Abstract}

Background Intimate partner violence (IPV) is a key public health and social concern among couples in countries globally. A systematic review was conducted to find out information that is found in relation to literature on perpetration of IPV among couples infected with human immunodeficiency virus (HIV). Objective The main objective of this study was to search for evidence of IPV among couples infected with HIV. Specifically, we reviewed literature related to the types of violence perpetrated by intimate partners who are infected with HIV and literature on their experiences.

Methods The literature review was guided by the frame work of Arksey and O'Maley (2005). The search engines used in the review include PubMed, CINAHL, MEDLINE, PsycINFO, and Google Scholar and was focused on perpetration of violence among HIV infected concordant or discordant couples.

Results Four main categories of violence were identified in the scoping review, namely psychological abuse, physical abuse, sexual victimization or abuse as well as other forms of abuse. We identified 61 literature related to the topic. Fifty-eight (58) articles were left after duplicates were removed, title and abstract screening brought the number to 9 for full article screening. Nine (9) full text studies were assessed out of the 58 and only 4 were included as they contained data on all the three categories of IPV: physical IPV, sexual IPV, and psychological IPV experienced as a result of being HIV positive. Other IPV identified included financial deprivation, prevention of the partner from meeting colleagues, and verbal abuse such as shouting and scornful looks.

Conclusions The results of the systematic review showed limited studies on the perpetration of IPV among HIV infected couples. It is recommended that further studies be done on exploring experiences of couples who perpetrate IPV among HIV seroconcordant or serodiscordant infected couples.Systematic review registration PROSPERO CRD42017062190

\section{Background}

Intimate partner violence (IPV) is a public and social concern worldwide and comes in the forms of physical, emotional and sexual abuse. These forms of abuse are found in populations globally (Hembling and Andrinopoulos 2014, Were et al. 2011). In sub-Saharan Africa, studies have reported high lifetime experience of IPV (Hembling and Andrinopoulos 2014). For example, a study in South Africa revealed $32 \%$ of young males perpetrating forms of abuse against their partners as reported (Were et al. 2011). Another study that was conducted in Kenya showed some prevalence of physical abuse (26\%) against female partners, $74 \%$ of which was perpetrated by intimate couples (Hembling and Andrinopoulos 2014).

IPV is a significant public health problem with some known relation to HIV infection and vulnerability as demonstrated by some studies in the literature (Hatcher et al. 2015, Hatcher et al. 2014). IPV is a key concern in sub-Saharan Africa which have links to HIV infections among couples which is yet to be explored in the sub-Saharan region particularly Ghana. In the review, pieces of evidence from the perpetration of IPV and HIV infection were explored using data from 2008 to 2018. According to Amoakohene (2004) literature around HIV infection is less known with regard to the influence of IPV among people living with the infection. There is some amount of literature that gives the indications that couples infected and living with the disease are more likely to experience violence in their relationships. This has been shown by some studies in areas with rich resources estimating that $68-95 \%$ of people living with the infection experience some IPV one time or the other (Cavanaugh and Gelles 2005, Amoakohene 2004, Jewkes et al. 2017). According to these studies, diagnosing someone of HIV infection in itself triggers some form of conflict and abuse in relationships. It is important to note that testing for HIV whether the individual tests positive or negative leads to some form of violence which suggests that testing for the disease alone may lead to risks of IPV among couples. Some studies have found that IPV as a result of HIV infection leads to decline in health. There is a relationship between IPV and HIV infection (Trimble, Nava, and McFarlane 2013, Jewkes et al. 2010). It is also important to note that negative attitude towards patient care and treatment because individuals are HIV positive can also be a reason for the perpetration IPV which is related to poor health results for couples living with infection (Hembling and Andrinopoulos 2014). In their view, some important reasons could account for the association between IPV and the poor health care results and these include being afraid of getting infected with the virus or continuous IPV which makes couples to refuse to disclose their statuses to their intimate partners, which definitely has an impact on treatment outcomes or adherence.

Scarcity of literature on best ways of preventing and minimising IPV and abuse among people living with HIV (PLWHIV) in some countries in the African subSaharan region is a concern (Sarnquist et al., 2014). Therefore, the need to review studies on IPV among HIV infected seroconcordant or serodiscordant partners to establish knowledge gaps and identify where primary research is essential. Hence, this study has explored the pieces of evidence of perpetration of IPV among HIV infected seroconcordant or serodiscordant partners.

\section{Methods}

\section{Purpose of the review}

The review methodology was undertaken following the approach of Arksey and O'Malley (2005). Reviews are important in showing evidence of literature around an area or topic that an individual shows interest in and this helps to concentrate and focus the research question and in doing so show some findings already in the area which helps in identifying knowledge gaps (Arksey and O'Malley 2005). PICO which means Population, Intervention, Comparison, and Outcome is a framework used to determine the criteria for eligibility in conducting primary research. See Table 1 for more information.

Table 1: PICO framework for definition of eligibility of studies for primary research question 
O-Outcomes Promotion of positive relationship among HIV infected couples, prevention of the spread of the virus and then improvement in the quality of life of individuals living with HIV (General well-being and health)

\section{Search strategy}

Search engines such as PubMed, CINAHL, MEDLINE, PsycINFO, and Google Scholar were employed as a means of searching for the information. We chose these search engines as a result of recommendations through discussions among the authors and that of a librarian, University of KwaZulu-Natal. The search was done from $7^{\text {th }}$ January to $3^{\text {rd }}$ May 2019 using the following keywords: "partner violence" "intimate partner" "violence perpetration" "HIV". Boolean terms such as AND/ OR were employed as a way of separating keywords. In order to get current literature in relation to intimate partner violence in LMICs, we limited the date of publication of included studies to studies done from 2007 to 2018 . Search language was also limited to English due to lack of expertise to translate studies published in other languages. Study design restriction was however removed.

Studies that were peer-reviewed were included as well as grey literature which were specific to the topic in order to address the research questions were chosen and included our study. We restricted our study to only articles published in the English language and between 2007 and 2018 . The reason for limiting this study to between 2007 and 2018 was due to lack of resources as stated by Apiribu, Ncama, and Joseph-Shehu (2019) in the published study protocol.

\section{Study selection}

The selection of the study happened in three stages. The screening of the titles was done by one screener using the eligibility criteria as a guide. The screening of the abstracts and full articles were done by two independent screeners (FA and DK). Any disagreements in the two screeners' responses were resolved through discussions until a consensus was reached. Disagreements in screeners' responses were resolved when full article screening was being done by the involvement of a third screener.

\section{Criteria for Eligibility}

\section{Criteria for Inclusion}

The following criteria were used in including studies:

1. Studies that were published in the English language

2. Published literature between January 2007 and August 2018

3. Reports of articles that were on perpetration of IPV among HIV infected partners

4. Reports of studies on IPV

5. Studies on all reviews including systematic reviews, meta-analysis, scoping reviews, peer-reviewed journal articles and rapid reviews

6. Study designs in relation to all types of studies like quantitative studies, qualitative studies, cohort studies, pilot studies, randomized control trial studies, cross-sectional studies and quasi-experimental study designs.

\section{Criteria for Exclusion}

The criteria for inclusion for this study included:

1. Interventions not including any form of IPV

2. Studies that are not related to HIV infected partners and IPV and those relating to reducing the prevalence of IPV and HIV infections.

3. Articles that have reports not relating to HIV/AIDS and IPV 
4. Studies not in the English language

5. Published studies before January 2007 and after August 2018

6. Published studies not relating to HIV infected adults who are in heterosexual relations.

\section{Data extraction}

Studies that were selected were thoroughly screened, read and data extracted based on their study setting, aim/objective, bibliographic details, targeted population, and study design, intervention, relevant outcomes of interest were extracted and significant outcome. Geographical location (rural or urban) as well as the country of the study were also relevant outcomes of interest that were also extracted. According to the World Bank Group report (2018), data on levels of income from countries were also obtained.

\section{Ethical consideration}

There was no need for ethical clearance as this was literature that was reviewed.

\section{Results}

Our search identified 61 unique records as shown in Fig. 1. Three (3) of the articles were duplicates out of the 61 leaving a total 58 articles. The authors did an assessment of 9 full-text articles for eligibility after title and abstract assessment of the 58 articles. Out of the 9 articles, 4 were included for analysis. The studies that were included are as seen in Table 1. Out of the 9 studies, the 4 articles included data on all the three forms of IPV: physical IPV, sexual IPV, and psychological IPV experienced as a result of being HIV positive. Other IPV identified included financial deprivation, prevention of the partner from meeting colleagues, and verbal abuse such as shouting and scornful looks. Of the four articles, two were conducted in India, one in South Africa and one in South-East Ethiopia. All the articles were within the lower middle income countries bracket. Most of the articles concentrated on the views of couples that had experienced violence in their relationships and were HIV positive or living with HIV. The tool for the mixed method Appraisal (MMAT) version 11(Pace et al. 2012) was employed to assess the quality of studies that were included. The authors appraised all relevant articles in the study in relation to the quality and methodology by employing the check lists for the MMAT for the outcomes of appraisal. The incentive for the decisions taken was kept for the purposes of auditing. The authors had the selected studies appraised by a second reviewer independently. A flowchart summarizing the selection process is as seen in Fig. 1 below:

Figure 1: A flow chart of the phases that were used for the literature search for the extraction of the most specific literature for the review.

Analysis of the Key Findings (Evidence Established)

Four main categories of violence were identified in the scoping review. These were physical violence, sexual violence, psychological violence and other types of violence. Under each of these headings were significant outcomes as seen in Table 2 below.

Table 2: Characteristics and findings of included studies 


\begin{tabular}{|c|c|c|c|c|c|c|c|c|c|}
\hline $\begin{array}{l}\text { Author and } \\
\text { date }\end{array}$ & Title & Study design & Country & Study setting & $\begin{array}{l}\text { Study } \\
\text { Population }\end{array}$ & Age & $\begin{array}{l}\text { Physical } \\
\text { violence }\end{array}$ & $\begin{array}{l}\text { Sexual } \\
\text { violence }\end{array}$ & $\begin{array}{l}\text { Psycl } \\
\text { violer }\end{array}$ \\
\hline $\begin{array}{l}\text { Hatcher AM } \\
\text { et al., } 2014\end{array}$ & $\begin{array}{l}\text { An } \\
\text { exploratory } \\
\text { qualitative } \\
\text { study design } \\
\text { using in- } \\
\text { depth } \\
\text { interviews } \\
\text { (IDIs) and } \\
\text { focus group } \\
\text { discussions } \\
\text { (FGDs) }\end{array}$ & South Africa & $\begin{array}{l}\text { An urban } \\
\text { setting in } \\
\text { three } \\
\text { Johannesburg } \\
\text { antenatal } \\
\text { clinics }\end{array}$ & $\begin{array}{l}\text { IPV and HIV- } \\
\text { related health } \\
\text { among } \\
\text { pregnant } \\
\text { women and } \\
\text { service } \\
\text { providers in } \\
\text { Johannesburg }\end{array}$ & $\begin{array}{l}\text { No age } \\
\text { limit }\end{array}$ & $\begin{array}{l}\text { hurting } \\
\text { emotionally, } \\
\text { insulting } \\
\text { using } \\
\text { words like } \\
\text { fool stupid } \\
\text { and idiot } \\
\text { and then } \\
\text { strangling } \\
\text { after HIV } \\
\text { positive } \\
\text { disclosure }\end{array}$ & $\begin{array}{l}\text { Refusal to } \\
\text { have sex with } \\
\text { the participant } \\
\text { after HIV } \\
\text { positive status } \\
\text { disclosure, } \\
\text { refusal to use } \\
\text { a condom and } \\
\text { having sex } \\
\text { with her } \\
\text { without her } \\
\text { consent }\end{array}$ & $\begin{array}{l}\text { Pregnant } \\
\text { women } \\
\text { described } \\
\text { experiencing } \\
\text { emotional } \\
\text { abuse and } \\
\text { abandonment } \\
\text { following } \\
\text { disclosure of } \\
\text { HIV to a } \\
\text { partner such } \\
\text { as coming } \\
\text { home late } \\
\text { and } \\
\text { eventually } \\
\text { leaving the } \\
\text { relationship. } \\
\text { they are } \\
\text { scared in } \\
\text { disclosing } \\
\text { their HIV } \\
\text { positive } \\
\text { status to their } \\
\text { partners }\end{array}$ & $\begin{array}{l}\text { womı } \\
\text { blam } \\
\text { perce } \\
\text { infide } \\
\text { for br } \\
\text { the di } \\
\text { into t } \\
\text { relatir }\end{array}$ \\
\hline $\begin{array}{l}\text { Chakraborty } \\
\text { et al., } 2016\end{array}$ & $\begin{array}{l}\text { Determinants } \\
\text { of Intimate } \\
\text { Partner } \\
\text { Violence } \\
\text { Among HIV- } \\
\text { Positive and } \\
\text { HIV-Negative } \\
\text { Women in } \\
\text { India }\end{array}$ & $\begin{array}{l}\text { A } \\
\text { quantitative } \\
\text { survey } \\
\text { design using } \\
\text { a } \\
\text { questionnaire } \\
\text { with a } \\
\text { sample size } \\
\text { of } 100 \\
\text { married } \\
\text { couples with } \\
\text { at least one } \\
\text { HIV positive } \\
\text { partner and } \\
100 \text { married } \\
\text { couples in } \\
\text { which neither } \\
\text { partner was } \\
\text { HIV positive }\end{array}$ & India & Urban clinics & $\begin{array}{l}\text { Married } \\
\text { couples } \\
\text { with HIV } \\
\text { positive } \\
\text { partner } \\
\text { and } \\
\text { married } \\
\text { couples }\end{array}$ & No age limit & $\begin{array}{l}\text { Push or shake } \\
\text { you, Throw } \\
\text { something at } \\
\text { you, Punch } \\
\text { you with his } \\
\text { hand, Kick or } \\
\text { drag you, Slap } \\
\text { you or twist } \\
\text { your arm Try } \\
\text { to strangle, kill, } \\
\text { or burn. Also } \\
\text { hitting/beating }\end{array}$ & $\begin{array}{l}\text { Forced sex } \\
\text { and none use } \\
\text { of condoms }\end{array}$ & $\begin{array}{l}\text { fear c } \\
\text { violer } \\
\text { disclc } \\
\text { and s }\end{array}$ \\
\hline $\begin{array}{l}\text { Deribe et al., } \\
2008\end{array}$ & $\begin{array}{l}\text { Disclosure } \\
\text { experience } \\
\text { and } \\
\text { associated } \\
\text { factors } \\
\text { among HIV } \\
\text { positive men } \\
\text { and women } \\
\text { clinical } \\
\text { service users } \\
\text { in southwest } \\
\text { Ethiopia }\end{array}$ & $\begin{array}{l}\text { A cross- } \\
\text { sectional } \\
\text { study design }\end{array}$ & $\begin{array}{l}\text { southwest } \\
\text { Ethiopia }\end{array}$ & $\begin{array}{l}\text { Jimma } \\
\text { University } \\
\text { Specialized } \\
\text { Hospital }\end{array}$ & $\begin{array}{l}\text { PLWHA } \\
\text { utilizing } \\
\text { various } \\
\text { ongoing } \\
\text { services in } \\
\text { the } \\
\text { hospital }\end{array}$ & $\begin{array}{l}\text { Aged } \\
18 \text { years } \\
\text { and above }\end{array}$ & $\begin{array}{l}\text { might beat or } \\
\text { hurt the } \\
\text { partner }\end{array}$ & $\begin{array}{l}\text { Denial of sex } \\
\text { and none use } \\
\text { of condoms }\end{array}$ & $\begin{array}{l}\text { negat } \\
\text { imag } \\
\text { negat } \\
\text { publii } \\
\text { attitu } \\
\text { discle } \\
\text { relate }\end{array}$ \\
\hline $\begin{array}{l}\text { Wilson et } \\
\text { al., } 2016\end{array}$ & $\begin{array}{l}\text { A prospective } \\
\text { study of } \\
\text { intimate } \\
\text { partner } \\
\text { violence as a } \\
\text { risk factor for } \\
\text { detectable } \\
\text { plasma viral } \\
\text { load in HIV- } \\
\text { positive } \\
\text { women } \\
\text { engaged in } \\
\text { transactional } \\
\text { sex in } \\
\text { Mombasa, } \\
\text { Kenya }\end{array}$ & $\begin{array}{l}\text { A prospective } \\
\text { cohort study }\end{array}$ & Kenya & Mombasa & $\begin{array}{l}\text { HIV- } \\
\text { positive } \\
\text { FSWs }\end{array}$ & $\begin{array}{l}\text { Age } 18 \text { or } \\
\text { older }\end{array}$ & $\begin{array}{l}\text { slapped, } \\
\text { pushed, hit, } \\
\text { kicked, } \\
\text { choked, } \\
\text { threatened or } \\
\text { used a } \\
\text { weapon }\end{array}$ & $\begin{array}{l}\text { physically } \\
\text { forced to } \\
\text { have sexual } \\
\text { intercourse } \\
\text { when they did } \\
\text { not want to, }\end{array}$ & $\begin{array}{l}\text { thing: } \\
\text { done } \\
\text { or int } \\
\text { partn } \\
\text { purpc } \\
\text { as loc } \\
\text { her, b } \\
\text { or sm } \\
\text { thing: }\end{array}$ \\
\hline
\end{tabular}


The four included studies identified a number of forms of physical violent among couples. The physical violence found by Hatcher et al (2014) included hurting emotionally, insulting words like a fool, stupid and idiot and then strangling after HIV positive disclosure by the partners. Pushing or shaking of the partners, throwing something at them, punching them with the hands, kicking or dragging them, slapping them or twisting their arms and trying to strangle, kill, or burn them were some of the physical violence perpetrated as identified by Chakraborty et al. (2016) in their study. They also found hitting or beating as physical violence in their findings. Again, Deribe et al. (2008) found no physical violence. However, they found failure to disclose sero-status because of fear of violence like yelling and rejection. Wilson et al. (2016) in their study found slapping, pushing, hitting, kicked, choking, threat or used a weapon to hit partners as some of the physical violence that was perpetrated among couples after sero-status disclosure.

\section{Sexual Violence}

All the articles found sexual violence among couples after sero-status disclosure (Hatcher et al. 2014, Chakraborty et al. 2016, Deribe et al. 2008, Wilson et al. 2016). Hatcher et al. (2014) found the refusal to have sex with the participant after HIV positive status disclosure, refusal to use a condom and having sex with her without her consent as sexual violence against particular the women. Forced sex and none use of condoms were those found by (Chakraborty et al. 2016) whilst (Deribe et al. 2008) found the denial of sex and none use of condoms as some of the sexual violence among couples. Wilson et al. (2016) found participants disclosing having been physically forced to have sexual intercourse when they did not want to have sex.

\section{Psychological Violence}

Here again, most participants in the four articles included in the study (Hatcher et al. 2014, Chakraborty et al. 2016, Deribe et al. 2008, Wilson et al. 2016) said they were psychologically abused when they disclosed their sero-statuses to their partners. Pregnant women described having experienced some emotional abuse and abandonment after they had disclosed of HIV positive status to their intimate partners such as coming home late and eventually leaving the relationship. They were also scared of telling their HIV infected statuses to their intimate partners (Hatcher et al. 2014). Fear of violence after disclosure and stigma found by Chakraborty et al. (2016) and negative self-image, negative public attitude, disclosure related stress were those found by (Deribe et al. 2008). (Wilson et al. 2016) identified in their study that participants did things to scare or intimidate their partners on purpose, such as looking at her scornfully, by yelling or smashing things.

Financial Abuse and other Forms of Violence

All the articles identified women are blamed for supposed unfaithfulness and also accused of bringing the infection into their relationship (Hatcher et al. 2014) financial deprivation (Chakraborty et al. 2016) lack of financial assistance ((Deribe et al. 2008)) keeps partner from visiting friends; they insist on knowing where their partners are always; are often suspicious that their partners are unfaithful and will need permission to get health care. They will deny them financial assistance (Wilson et al. 2016) as some violent activities found in the included articles.

\section{Significant Findings}

Some significant outcomes in this review include detectable plasma virus load, poor antiretroviral therapy (ART) adherence in the past month (Wilson et al. 2016), discussing about testing with one's partner before seeking health service is significantly associated with disclosure (Deribe et al. 2008). Again, cultural context in which prevention programs are targeted and counseling and support services for HIV-infected females (Chakraborty et al. 2016) were significant outcomes and finally, the diagnosis for HIV during pregnancy was found to be a trigger of violence. Declines in mental health were noted in women experiencing IPV in pregnancy and IPV led to secondary HIV risk when women were in relationships with forced sex or without power to negotiate condom us (Hatcher et al. 2014).

\section{Discussion}

From Table 1 above, there were four articles (Hatcher AM et al., 2014; Chakraborty et al., 2014; Deribe et al., 2008 \& Wilson et al., 2016) that were extracted for the study. In spite of much attention to HIV and IPV, international policy consensus on the need to facilitate safer disclosure of HIV status for women who experience or fear violence (Kennedy et al. 2015), we identified only four studies evaluating such studies globally. None of the four articles provided obvious evidence for the perpetration of IPV by men after the disclosure of the HIV statuses of their partners as this did not separate the contribution of the safer disclosure components from the broader multiple- component interventions as identified. The evidence for the four studies does not support safer disclosure and prevention of IPV making it quite limited, and so more studies will be required in this area.

Hatcher et al. (2014) conducted their study on bidirectional links between HIV and IPV in pregnancy: implications for prevention of mother-to-child transmission where they used an exploratory qualitative study design and in-depth interviews (IDIs) as well as focus group discussions (FGDs) in three urban clinics in South Africa. The population was pregnant women and service providers in Johannesburg. The main findings were that there were the perpetration of physical violence, sexual violence, psychological violence as well as other forms of violence such as women being blamed for alleged unfaithfulness and also being accused for bringing the infection into the family. The most important outcomes were the diagnosis of HIV during pregnancy which served as a trigger for IPV, there was also reduction in mental health which was noticed in women who had experienced IPV during pregnancy and IPV resulted in secondary risk for HIV infection when female partners had forced sex in their relationships or were without the power to negotiate the use of condoms (Hatcher et al. 2014). The second article was by (Chakraborty et al. 2016) who used a quantitative survey design and questionnaire and a sample size of 100 married partners with at least one of them being HIV positive and 100 married partners who were both not HIV positive. They found that there were the perpetration of physical, sexual, psychological as well as financial deprivation. The outcomes as identified in this study were that prevention programs were provided as well as the provision of counseling and support services for HIV-positive women (Chakraborty et al. 2016). The third study that was included for this review was that of (Deribe et al. 2008) who conducted their study on "Disclosure experience and associated factors among HIV positive men and women 
clinical service users in south-west Ethiopia". The main categories of violence identified were physical violence, sexual violence, psychological violence as well as lack of financial support. The main outcomes were that discussing with one's partner about testing for HIV before seeking health service was significantly associated with disclosing the HIV status (Deribe et al. 2008). The final and fourth study was by (Wilson et al. 2016) who conducted their study entitled "A prospective study of IPV as a risk factor for detectable plasma viral load in HIV-positive women engaged in transactional sex in Mombasa, Kenya". The main findings were significantly similar to (Chakraborty et al. 2016, Deribe et al. 2008, Hatcher et al. 2014) with the exception of findings such as keeping partner from visiting friends; insisting on knowing the whereabouts of their partners always; always suspicious that they are unfaithful; Requiring permission to seek health care and denying them financial assistance. The four studies; (Chakraborty et al. 2016, Deribe et al. 2008, Hatcher et al. 2014, Wilson et al. 2016), even though had some important findings on intimate partner violence, there is lack of studies on men perpetrating intimate partner violence following disclosure of the female partners or both. There is, therefore, the need to do a study to determine the views of men perpetrating violence against their female intimate partners following the disclosure of their HIV positive statuses.

\section{Conclusion}

The findings of these studies suggest that disclosing the HIV status among couples needs to be improved as fear of IPV is significantly high. Although these findings may serve as the starting point data for HIV disclosure, more data on HIV infection status disclosure is important. Experiences of perpetrators of IPV against HIV positive partners were also limited and need to be explored by studies in this area. Finally, disclosure of HIV status to an intimate partner has significant importance in preventing new infections as well as preventing the perpetration of IPV against HIV sero-positive couples. The authors of this study suggest that prevention of HIV infection should target male perpetrators of IPV against their female sero-positive partners in order to institute positive behavioural changes in partners.

\section{Declarations}

\section{Ethical Approval and Consent to participate}

Not applicable

Consent for Publication

All the authors have consented to the publication of the manuscript.

Availability of Supporting Data

All data in relation to this manuscript will be made available on request since the major data is already part of the manuscript.

\section{Competing Interests}

The authors hereby declare that they have no financial or personal relationship(s) which may have inappropriately influenced them in writing this article.

\section{Funding}

There was no funding for this manuscript.

\section{Authors' Contributions}

FA contributed to the conception and generation of the review, planning, conduction, analysis and interpretation of the data as well as the design and together with DK wrote the manuscript. BPN reviewed the manuscript thoroughly and gave administrative support and advice. DK helped in the full article screening and the writing of the manuscript with FA. All authors read and approved the final manuscript.

\section{Acknowledgements}

This research was partially funded by the CHS Ph.D. Scholarship grant awarded by the College of Health Sciences, University of KwaZulu-Natal, Durban. The assistance of the staff of the College of Health Sciences and the School of Nursing and Public Health, University of KwaZulu-Natal is gratefully acknowledged. We also wish to acknowledge the contributions of Tivani P. Mashamba-Thompson for her immense contribution to this work.

Authors' Information

There was no information necessary to be written.

\section{References}

Amoakohene, Margaret Ivy. 2004. "Violence against women in Ghana: a look at women's perceptions and review of policy and social responses." Social Science \& Medicine 59 (11):2373-2385. doi: http://doi.org/10.1016/j.socscimed.2004.04.001.

Apiribu, F., B. P. Ncama, and E. Joseph-Shehu. 2019. "Evidence of perpetration of intimate partner violence among HIV-positive couples: a systematic scoping review protocol." Syst Rev 8 (1):159. doi: 10.1186/s13643-019-1051-3.

Arksey, H. , and L. O'Malley. 2005. "Scoping studies: towards a methodological framework." International Journal of Social Research Methodology 8 (1):19-32. 
Arksey, Hilary, and Lisa O'Malley. 2005. "SCOPING STUDIES: TOWARDS A METHODOLOGICAL FRAMEWORK." International Journal of Social Research Methodology: Theory \& Practice 8 (1):19-32.

Cavanaugh, Mary M, and Richard J Gelles. 2005. "The utility of male domestic violence offender typologies: New directions for research, policy, and practice." Journal of interpersonal violence 20 (2):155-166.

Chakraborty, H., S. Patted, A. Gan, F. Islam, and A. Revankar. 2016. "Determinants of Intimate Partner Violence Among HIV-Positive and HIV-Negative Women in India." J Interpers Violence 31 (3):515-30. doi: 10.1177/0886260514555867.

Deribe, K., K. Woldemichael, M. Wondafrash, A. Haile, and A. Amberbir. 2008. "Disclosure experience and associated factors among HIV positive men and women clinical service users in Southwest Ethiopia." BMC Public Health 8:81. doi: 10.1186/1471-2458-8-81.

Hatcher, Nataly Woollett, Christina C. Pallitto, Keneuoe Mokoatle, Heidin Stöckl, Catherine MacPhail, Sinead Delany-Moretlwe, and Claudia García-Moreno. 2014. "Bidirectional links between HIV and intimate partner violence in pregnancy: implications for prevention of mother-to-child transmission." Journal of the International AIDS Society 17 (1):19233. doi: 10.7448/ias.17.1.19233.

Hatcher, A. M., E. M. Smout, J. M. Turan, N. Christofides, and H. Stockl. 2015. "Intimate partner violence and engagement in HIV care and treatment among women: a systematic review and meta-analysis." AIDS29 (16):2183-94. doi: 10.1097/QAD.0000000000000842.

Hembling, J., and K. Andrinopoulos. 2014. "Evidence of increased STI/HIV-related risk behavior among male perpetrators of intimate partner violence in Guatemala: results from a national survey." AIDS Care 26 (11):1411-8. doi: 10.1080/09540121.2014.913766.

Jewkes, R., E. Fulu, R. Tabassam Naved, E. Chirwa, K. Dunkle, R. Haardorfer, C. Garcia-Moreno, U. N. Multi-country Study on Men, and Team Violence Study. 2017. "Women's and men's reports of past-year prevalence of intimate partner violence and rape and women's risk factors for intimate partner violence: A multicountry cross-sectional study in Asia and the Pacific." PLoS Med 14 (9):e1002381. doi: 10.1371/journal.pmed.1002381.

Jewkes, Rachel K., Kristin Dunkle, Mzikazi Nduna, and Nwabisa Shai. 2010. "Intimate partner violence, relationship power inequity, and incidence of HIV infection in young women in South Africa: a cohort study." The Lancet 376 (9734):41-48. doi: 10.1016/s0140-6736(10)60548-x.

Kennedy, Caitlin E, Sabina Haberlen, Avni Amin, Rachel Baggaley, and Manjulaa Narasimhan. 2015. "Safer disclosure of HIV serostatus for women living with HIV who experience or fear violence: a systematic review." Journal of the International AIDS Society 18 (5). doi: 10.7448/IAS.18.6.20292.

Pace, Romina, Pierre Pluye, Gillian Bartlett, Ann C. Macaulay, Jon Salsberg, Justin Jagosh, and Robbyn Seller. 2012. "Testing the reliability and efficiency of the pilot Mixed Methods Appraisal Tool (MMAT) for systematic mixed studies review." International Journal of Nursing Studies 49 (1):47-53. doi:

10.1016/j.jinurstu.2011.07.002.

Trimble, Debra D, Angeles Nava, and Judith McFarlane. 2013. "Intimate partner violence and antiretroviral adherence among women receiving care in an urban Southeastern Texas HIV clinic." Journal of the Association of Nurses in AIDS Care 24 (4):331-340.

Were, E., K. Curran, S. Delany-Moretlwe, E. Nakku-Joloba, N. R. Mugo, J. Kiarie, E. A. Bukusi, C. Celum, J. M. Baeten, and Hsvhiv Transmission Study Team Partners in Prevention. 2011. "A prospective study of frequency and correlates of intimate partner violence among African heterosexual HIV serodiscordant couples." AIDS 25 (16):2009-18. doi: 10.1097/QAD.0b013e32834b005d.

Wilson, K. S., G. Wanje, K. Yuhas, J. M. Simoni, L. Masese, A. Vander Stoep, W. Jaoko, J. P. Hughes, B. A. Richardson, and R. Scott McClelland. 2016. "A Prospective Study of Intimate Partner Violence as a Risk Factor for Detectable Plasma Viral Load in HIV-Positive Women Engaged in Transactional Sex in Mombasa, Kenya." AIDS Behav 20 (9):2065-77. doi: 10.1007/s10461-016-1420-z.

The World Bank Group report, (2018). BANK TW. ANNUAL REPORT 2018. Retrieved from:

https://www.doingbusiness.org/content/dam/doingBusiness/media/Fact-Sheets/DB18/PT18CentralAsiaEasternEuropeFactSheetEnglish.pdf

\section{Figures}




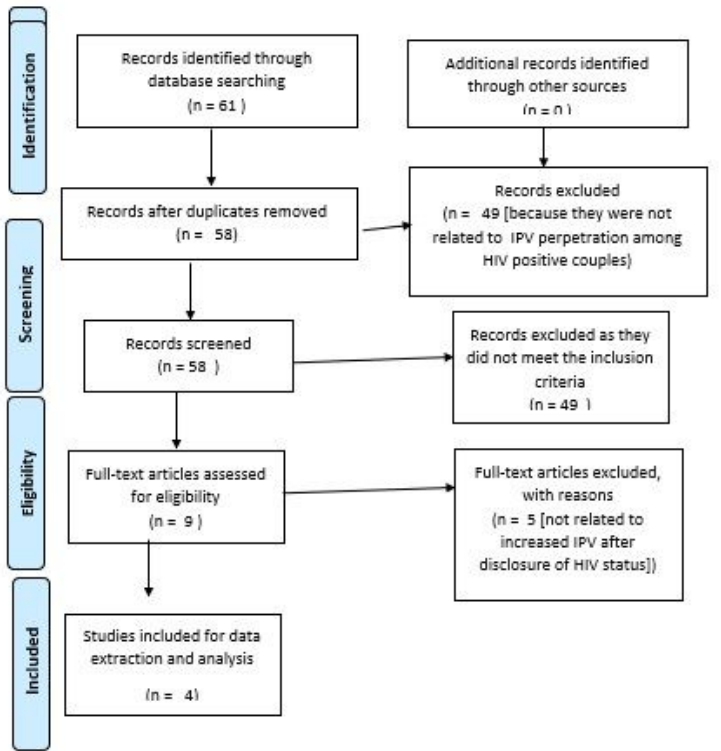

Figure 1

A flow chart of the phases that were used for the literature search for the extraction of the most specific literature for the review. 